\title{
COMMTTEE
}

Chairman: H. G. Nicholas (New College, Oxford)

Secretary: Professor. Esmond Wright (Department of History, The University, Glasgow)

Treasurer: Dr. Dennis Welland (Department of English, The University, Nottingham)

Frofessor H. C. Allen (Department of History, University College,

Dr. William Brock London)

Dr. B. R. Crick

(Selwyn College, Cambridge)

(London School of Economics)

Professor J. A. Hawgood (Department of History, The University, Birmingham)

C. P. Hill

(Garden Flat, River Bend, Sea Walls Road, Bristol, 9)

Geoffrey Moore

(Department of English, The University,

R. H. Pear Manchester)

Frank Thistlethwaite (St. John's College, Cambridge)

Editor of the "Bulletin": George Shepperson (Department of History, The University, Edinburgh, 8)

(" indicates year in which committee-member are required to vacate their places or offer themselves for re-election)

\section{ADVISORY COIJNCIL}

Nr. Herbert Agar; Professor D. W. Brogan; Professor A. L. Goodhart; Sir Hector Hetherington; Dame Lillian Penson; Sir Sydney Roberts.

\section{EDITORIAL NOTES}

A new "Bulletin"? At the last annual general meeting of the Association it was suggested that the Bulletin should appear in a more durable form. For some time, the Committee has been aware of the necessity for this. Inquiries were made about the cost of printing the Bulletin, from which it became clear that, unless it were to receive a regular subsidy from an outside body, this would not be possible.

The Committee, therefore, is now considering the possibility of producing the Bulletin by the photo-offset process or one of the kindred methods of reproduction. Estimates which have already been recoived suggest that, ultimately, the Association may be able to bring out its Bulletin in this way. But, even by this process, costs will be high and it may be some time before the Committee will feel that it is in the position to allot a substantial proportion of the Association's already limited finances to producing a new type of Bulletin.

Furthermore, such a Bulletin will mean changes in format and content. Over the last two years, the character of the Bulletin has been altered considerably by the introduction of articles and by the emergence last summer of a B.A.A.S. Newsletter. A new type of Bulletin will mean much greater changes. 
B.A.A.S. members were sent recently a leaflet asking for suggestions about methods of reproducing a new kind of B.A.A.S. Bulletin and for comments and contributions. The Editor would like to repeat this appeal.

The B.A.A.S. Bulletin of the future will depend even more than it has done in the past on the support and suggestions of members.

"Trivia" and a Correspondence Column. It has been suggested that the Billetin should include these features.

Mr. Peter Marshall of Bristol University thinks that members would find interesting a page of Anglo-American "trivia" similar to the "trivia" section of The William and Mary Quarterly. As an example, Mir. Marshall quotes from. The Amberly Papers (London; 1937), II, pages 498-9, in which Lady Amberly wrote to Lady Stanley of Alderly in 1872, "Yesterday we all went to the servants' cricket match and to have tea at the White Lodge with the Tecls; there was no one there but the Duchess of Cambridge who received me by saying, 'I know you are the' daughter in law but now I hear you only like dirty people and dirty Americans. All London is full of it; all the clubs are talking of it. I must look at yr petticoats to sec if they are dirtiy." "I Members who encounter Anglo-American references which might be noted for the amusement and even the instruction of others in a "trivia" section of the Bulletin are encouraged to send them to the Editor.

A Correspondence Column has, in effect, been in existence since Mr. Marcus Cunliffe brought out the first Bulletin in April 1956. Interesting letters are always welcome and, more than once, the editors of the Bulletin have tried to start epistolary controversies.

The first B.A.A.S. Chairman. The resignation of Mr. Frank Thistlethwaite as chailman of the Association will be noted with regret by all members. Mr. Thistlethwaite has held this office since the Association was formed in 1955. His wise counsels have proved of inestimable value to the B.A.A.S. during its formative period. It is good to note that Mr. Thistlethwaite has consented to serve on the Committee for the next three years and that, in this way, the Association will continue to benefit from his advice.

\section{CONTRIBUTORS TO THIS ISSUE}

BRITISH. Mr. Anthony H. AIIt is Senior History Master of the Varndean Gramar School for Boys, Brighton. Dx, B. R. C. Crick is a Lecturer in Government at the London School of Economics. He has been in the news recently for his Fabian Society panphlet on reform of Parliament. Mr. J.F. C. Harrison is Deputy Director of Extra-itural Studies at Leeds University. Nr. Peter Marshall is a Lecturer in History at Bristol University. Mr. George Shepperson is Lecturer in Imperial and Anerican History at Edinburgh University. Dr. P. A. . Taylor is Resident Tutor for Dudley and South-West Staffordshire for Birmingha= University's Department of Extra--ilural Studies. He has been working on Morno: history for many years. Professor Esmond Wright is Professor of Modern History at Glasgow University.

AMERICAN. Professor John Hope Franlin is Chairman of the History Department at Brooklyn College, New York. He is the author of numerous books and articles on the Negro in Anerica, the most notable of which are probably Fron Slavery to Freedor and The Militant South. He has lectured in many parts of world on Negro problens. Professor Robert E. Spiller teache American Literat: at Pennsylvania University. He is probably best known in this country as the author of the standard Literary History of the United States. During 1958-195i he was a Senior Fulbright Visiting Professor at London University. 